\title{
The Pliocene and Quaternary sedimentary and fluvial history in the Upper Rhine Graben based on heavy mineral analyses
}

\section{E.-M. Hagedorn ${ }^{1, *}$ \& W. Boenigk ${ }^{2}$}

1 Leineweberstr. 9, D-51381 Leverkusen, Germany.

2 Geologisches Institut, Universität zu Köln, Zülpicher Str. 49 A, D-50674 Köln, Germany

* Corresponding author. Email: eva.hagedorn@gmx.de

Manuscript received: February 2005; accepted: July 2007

\section{Abstract}

The Pliocene and Quaternary unconsolidated sediments of the Upper Rhine Graben (URG) were petrographically analysed in numerous high quality drill cores. The heavy mineral composition of the Graben sediments was compared to those from the Graben margins. In addition, the sedimentary lithofacies were investigated. The chronological classification of the sedimentary successions was established by the interpretation of sporadic palaeontological and palaeomagnetic data.

Within the Pliocene sediments, two distinguishable heavy mineral assemblages indicate different source areas of the Graben fill. At first, a heavy mineral assemblage of stable minerals (turmaline, zircon and anatase) indicates a contribution of debris supplied from Buntsandstein areas at the Graben margins. Secondly, a mixed association of stable minerals in combination with unstable (garnet, hornblende, less epidote) and distinct rare minerals (e.g. monazite, xenotime) can be traced back to debris derived from the crystalline rocks of the southern Graben margins (Black Forest, Vosges). The distribution of sediments with this mixed heavy mineral assemblage proves the fluvial sediment transport from south to north and therefore the course of the Pliocene proto-Rhine along the Graben.

The correlation between the Quaternary sediment successions in the south and the north of the Graben is problematic due to their variable thicknesses as well as their changing lithofacies.

In the southern URG, the Quaternary strata could be subdivided into the older Breisgau Formation and the younger Neuenburg Formation based on characteristic lithofacies. Within this succession, the lower part of the Breisgau Formation (lower Breisgau beds) can be distinguished by noticeable lower contents of hornblende, which probably reflects the effects of weathering and solution of these unstable minerals due to repeated discontinuities during the sediment accumulation. The sediments of the upper part of the Breisgau Formation (upper Breisgau beds) and of the Neuenburg Formation contain a heavy mineral assemblage of garnet, epidote and hornblende, which is typical for Rhine deposits with Alpine contribution. This probably unaffected composition indicates a more unvaried and rapid accumulation of predominantly Alpine debris. In the northern URG, the Quaternary strata are subdivided into three aquifers and intercalated fine-grained horizons. Here, the Quaternary sediments can be petrographically classified into Rhine deposits (garnet, epidote and hornblende) and local accumulations contributed from the Graben margins (turmaline, zircon and anatase) without contemporaneous influence of the Rhine. The analytical results obtained from several drill cores in the northern URG provide evidence for the spatial and temporal variability of the course of the Rhine during the Quaternary.

Keywords: heavy minerals, lithofacies, Pliocene, Quaternary, stratigraphy, Upper Rhine Graben, Germany

\section{Introduction}

The URG has been an area of subsidence since the Eocene. This basin was subsequently filled with thick sedimentary successions. After various episodes of marine ingressions, the strata of Late Miocene, Pliocene and Quaternary age indicate a fluvial to lacustrine depositional environment.

The traditional lithostratigraphy of the Late Tertiary and Quaternary sediments within the URG was established by Bartz (1959, 1976, 1982; Fig. 1). On the basis of numerous drilling 


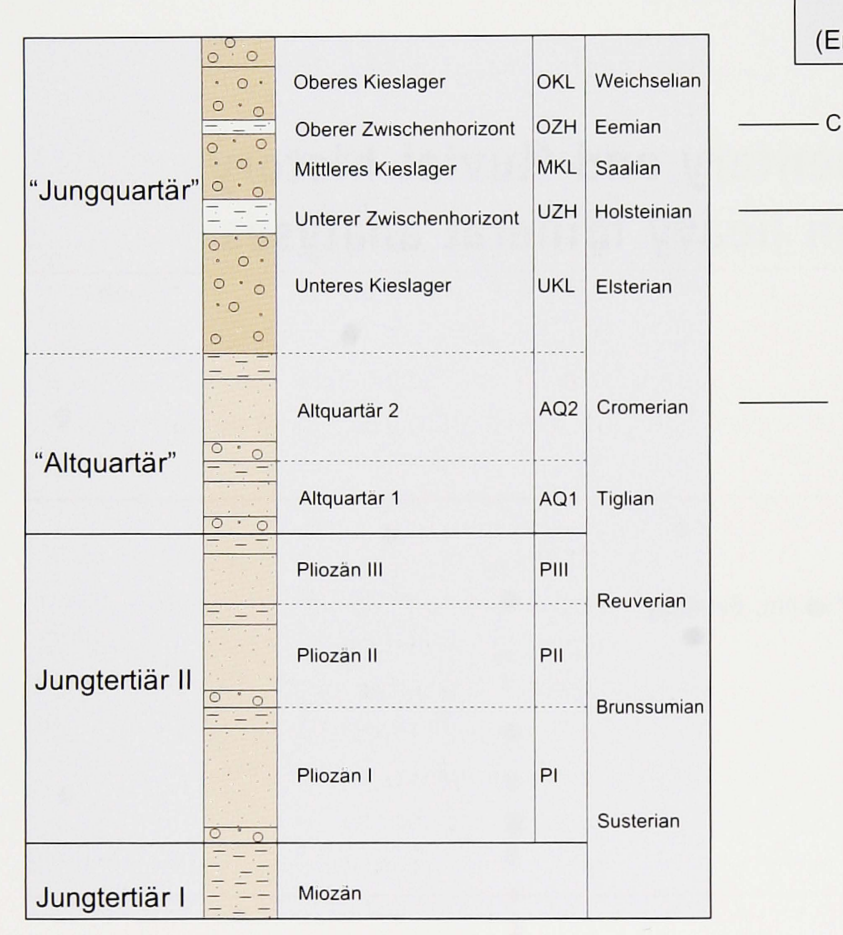

profiles - mainly in the middle and northern part of the Graben - Bartz subdivided the Pliocene sediment succession ('Jungtertiär II') into three fluvial to lacustrine sequences (PI, PII, PIII). The boundary between Pliocene and Quaternary strata was defined by the first occurrence of Alpine input into the Graben indicated by the carbonate content within the sediments as well as by their changing heavy mineral distribution. Among the Quaternary sediments, Bartz distinguished the 'Altquartär' (Early Quaternary), mostly sands and clays, and the 'Jungquartär' (Late Quaternary) consisting of three coarse-grained layers ('Kieslager') separated by two finer grained horizons 'Zwischenhorizonte', OZH, UZH).

Bartz correlated the formation of the coarse gravel layers with the last three glacial periods, the development of the fine-grained horizons with the interglacial periods Eemian and Holsteinian (Fig. 1). Sporadic pollen analyses led to the classification of 'Altquartär' and Pliocene (Bartz, 1976, 1982). However, the described lithostratigraphy can only be applied to the northern part of the URG, where the two fine-grained horizons are continuous, while further to the south they are partly or entirely absent.

Next, the simplified definition of the Pliocene/Pleistoceneboundary has to be reconsidered as new data available through heavy mineral analyses and palaeontological findings indicate a Late Pliocene age of the first Alpine sediment input into the Graben (Geissert, 1972; Münzing, 1981; Boenigk, 1987). More discrepancies resulted from the investigated mollusc assemblage within the 'Oberer Zwischenhorizont' (OZH, upper fine-grained horizon), which indicate an age from Cromerian to Rissian (Saalian) for this unit (Engesser \&

\section{Molluscs \\ Engesser \& Münzing, 1991)}

Cromerian to Rissian (Saalian)

Cromerian to Late Würmian (Weichselian)

Three different interglacials

(Early Pleistocene)
Fig. 1. Traditional lithostratigraphy of the unconsolidated sediment record in the Upper Rhine Graben (table modified after Bartz, 1959, 1976, 1982) versus biostratigraphical evidence (Engesser \& Münzing, 1991; Bludau, 1995).

Münzing, 1991), whereas Bartz correlated this horizon to the Eemian interglacial period. The classification of the 'Altquartär', also seems questionable as Pliocene species of fauna and flora dominate this section (Münzing, 1981; Engesser \& Münzing, 1991; Geissert, 1996).

Pollen analyses (Bludau, 1995) allowed the biostratigraphical distinction of three different interglacial pollen facies of Early Pleistocene age within the sediments of the 'Unterer Zwischenhorizont' (lower fine-grained horizon, UZH), while the 'Oberer Zwischenhorizont' (OZH) contains flora of the period Cromerian to Late Würmian (Weichselian).

The inconsistencies between the lithostratigraphy established by Bartz and new chronological evidences as outlined above instigated this research project, which is mainly concerned with the reconstruction of the sedimentary history of the Pliocene and Quaternary sediments in the URG (stratigraphy after STD, 2002, Southwest-Germany).

\section{Methods}

As part of a doctoral research project (Hagedorn, 2004), numerous (56) new high-quality deep drilling cores in the area of the URG have been studied in cooperation with the Geological Surveys of Baden-Württemberg, Rheinland-Pfalz, Hessen and Elsass. This study focussed on the lithofacies and heavy mineral analyses. Biostratigraphic and magnetostratigraphic analyses were carried out by other researchers (Rolf et al., 2008).

First, the drill cores have been recorded according to techniques of sequence and event stratigraphy (Ellwanger et 
al., 2001, 2002, 2003). Subsequently, the cores and several sediment outcrops at the Graben margins were sampled for petrographical analyses (Fig. 2). The heavy mineral analysis gives evidence to the regional provenance, transport of the sediments and post-sedimentary processes.

A total of 1340 heavy mineral samples were analysed according to methods described by Boenigk (1983). The data obtained during this project have been evaluated in combination with published and unpublished data of previous studies (e. g. Van Andel, 1950; Maus in Bartz, 1982; Boenigk, 1987 and unpublished Geological Survey reports). While the described methods allow the identification and correlation of lithostratigraphic units within the URG, their age and therefore their position within the Pliocene and Quaternary stratigraphic record is still uncertain, as chronological data for these sediments are still very limited. Biostratigraphic markers like pollen, molluscs etc., which occur in the fine-grained sediments of the northern URG, are the only information about the chronological classification of the sequences. The combined evaluation of the new data from this interdisciplinary approach contributed interpretations with respect to the development and the stratigraphic organisation of the Pliocene and Quaternary sediments of the URG.

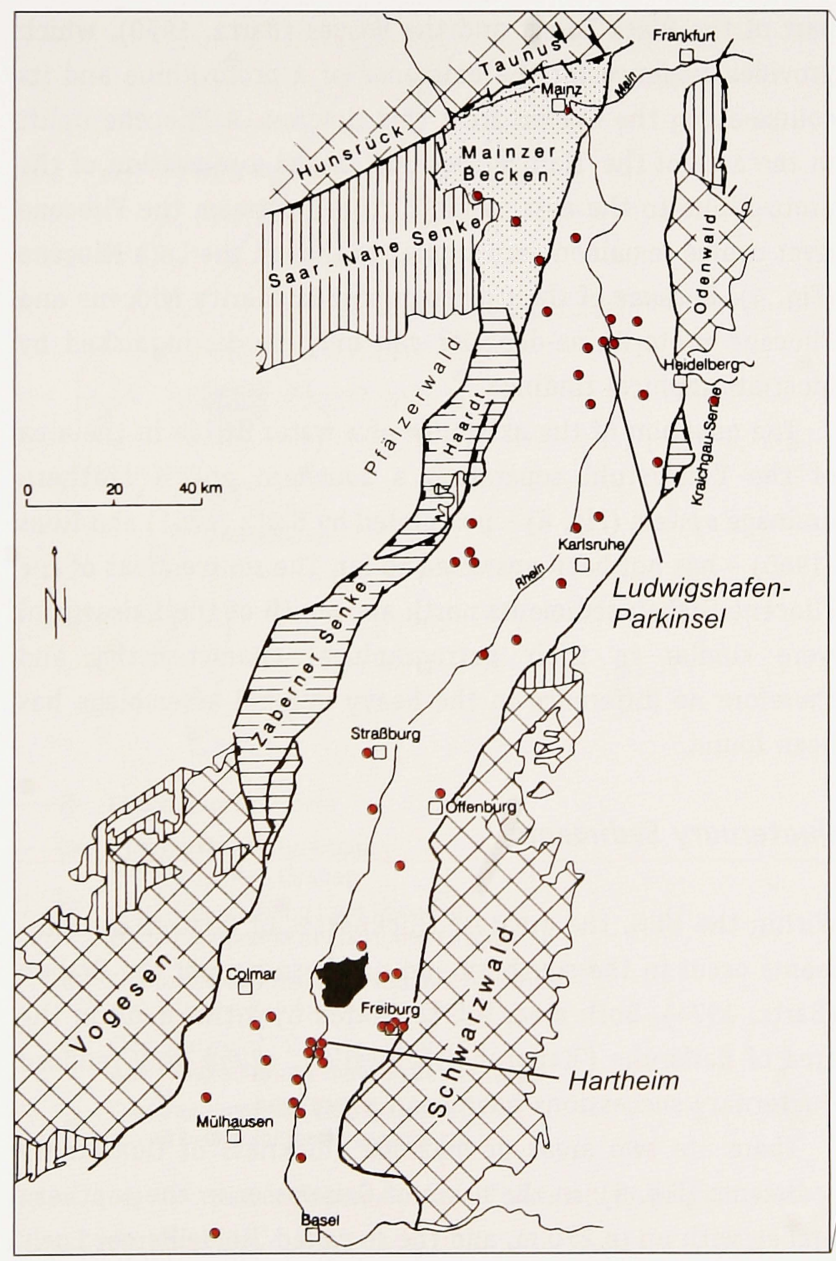

\section{Results and discussion}

\section{Pliocene Sediments}

The Pliocene sediments in the Graben area are predominantly fine-grained. Sandy clays alternate with sands of fine to medium grain size and some peat layers. Gravel layers only occur sporadically. Deposits of Pliocene age are thickest in the northern part of the URG with 200 to over $500 \mathrm{~m}$ (maximum: $640 \mathrm{~m}$ in drilling Heidelberger Radium-Sol-Therme, Bartz, 1953). In the middle part of the URG, the Pliocene sediments are restricted to a belt, where they occur with thicknesses of 60 to $100 \mathrm{~m}$ (Fig. 3).

While previous studies (Bartz, 1974) reported that Pliocene sediments in the southern part of the URG are absent due to erosion, Pliocene deposits were identified in some new drillings south of the Kaiserstuhl by means of their heavy mineral assemblage (Fig. 3). They have probably been preserved in this area in protected local depressions.

Heavy mineral assemblages obtained by Pliocene sediments have previously been described as associations of predominantly stable minerals. In contrast, the new data revealed that in fact two heavy mineral assemblages can be distinguished (Fig. 4).

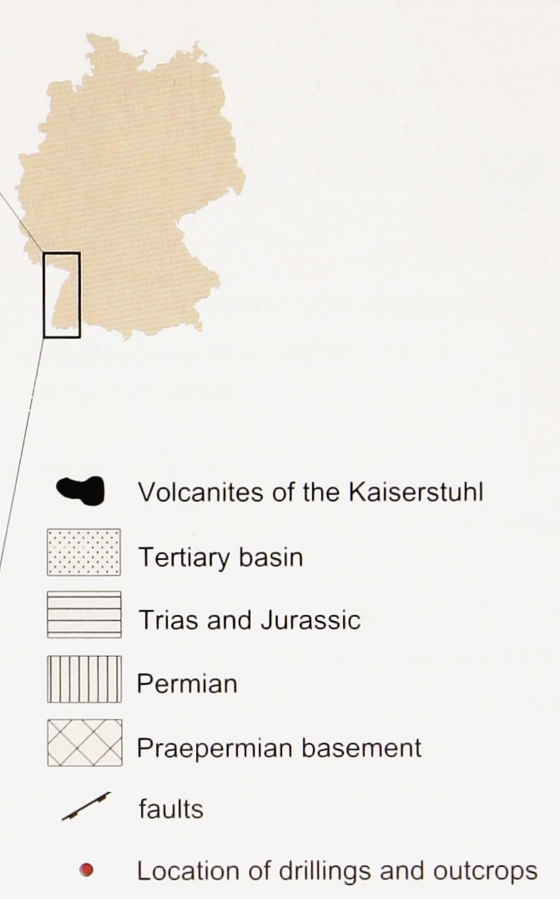

Fig. 2. Location of drillings and outcrops within the URG; location of drill cores Hartheim and Ludwigshafen-Parkinsel (map modified after Walter, 1992). 


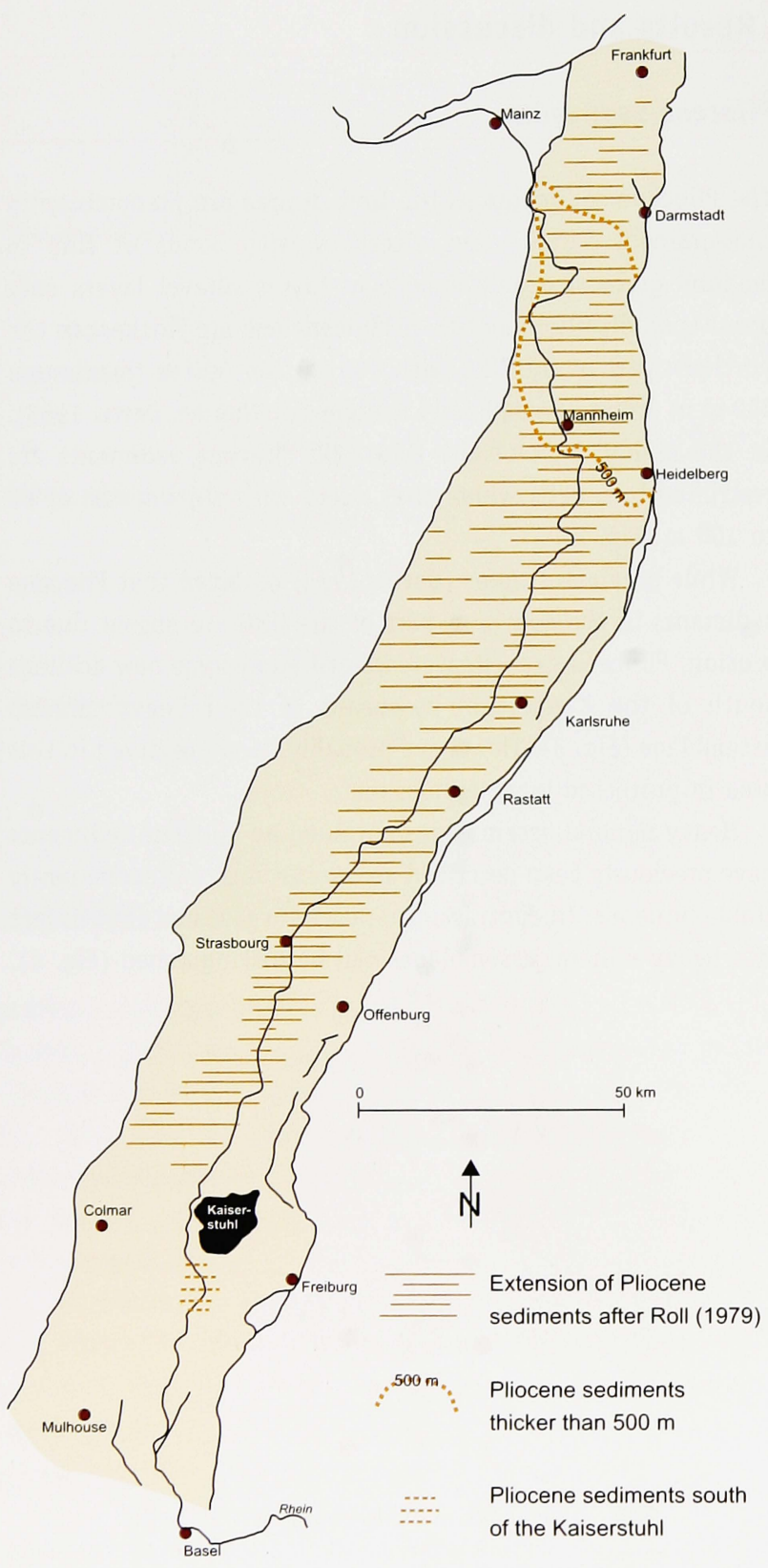

Fig. 3. Extension of Pliocene sediments (modified after Roll, 1979). Occurrence of Pliocene sediments south of the Kaiserstuhl, detected by several new drillings.

The first heavy mineral assemblage is dominated by the stable minerals zircon, turmaline and anatase, and is comparable to the previously reported assemblage. The other type of heavy mineral distribution contains higher percentages of unstable minerals (garnet and hornblende, less epidote) and a few distinctive rare minerals (monazite, xenotime, brookite, sphene) in addition to the stable minerals. Sediments with this mixed heavy mineral assemblage occur in several drill cores in the centre of the Graben (Fig. 4).

Pliocene sediments with mixed heavy mineral assemblages result from the contribution of debris derived from the crystalline rocks of the Black Forest and the Vosges into the Graben (cf. analyses from Maus in Bartz, 1982), which were further transported to the north by a Pliocene proto-Rhine. This interpretation is supported by comparison with recent fluvial sediments of these Graben margins, which show strong similarities in their mineral composition to those observed in the Pliocene sediments with mixed heavy mineral assemblage. Another important implication of this observation is, that the distribution of this sediment type (here also referred to as 'fluvial Rhine-facies') indicates the paleo-course of the Rhine during the Pliocene, which can be traced along the URG through the drilling profiles (Fig. 4).

In contrast, the heavy mineral spectrum dominated by stable minerals suggests sources in the Buntsandstein areas at the Graben margins, but may also be due to a higher degree of weathering of the source material ('Weisses Pliozän'). However, as Pliocene sediments of this type mainly occur close to the Graben margins, a Buntsandstein source appears to be a more likely explanation.

Sediments with a mixed (stable and instable) heavy mineral assemblage have previously been classified as Miocene deposits in analogy to the Late Miocene 'Dinotheriensande' in the 'Mainzer Becken' (Fig. 2), which show a similar mineral association (Boenigk, 1987). The Miocene deposits in the 'Mainzer Becken' contain also gravel derived from the northern part of the Black Forest and the Vosges (Bartz, 1950), which provides evidence for the existence of a proto-Rhine and its course along the Graben from this time on. A Pliocene uplift in the area of the 'Mainzer Becken' caused a relocation of the proto-Rhine to the east, while further upstream the Pliocene river course remained very similar to that in the Late Miocene (Fig. 4). Because of their petrographic similarity Miocene and Pliocene proto-Rhine-deposits can only be distinguished by biostratigraphical findings.

The question of the existence of a water divide in the area of the Kaiserstuhl separating a southern and a northern drainage system (Fig. 4) - postulated by Bartz (1961) and Illies (1965) - has not been answered so far. The source areas of the Pliocene Graben sediments north and south of the Kaiserstuhl were similar in their petrographical characteristics and therefore no difference in the heavy mineral assemblage has been found.

\section{Quaternary Sediments}

Within the URG, the greatest thicknesses of Quaternary sediments occur in the southern and northern part of the Graben (Bartz, 1974). Both areas are separated by a threshold in the area of Karlsruhe ('Karlsruher Schwelle'), where only reduced Quaternary successions have been preserved.

There are two areas of maximal thickness of Quaternary sediments (Fig. 5): in the basin of Geiswasser in the southern Graben with up to $270 \mathrm{~m}$, and the so called 'Heidelberger Loch' 
(Heidelberg basin) where a former drilling (Heidelberger Radium-Sol-Therme) revealed a maximal thickness of $382 \mathrm{~m}$ (Bartz, 1953). In contrast, the Quaternary successions in the area of the 'Karlsruher Schwelle' amount to only 30 to $60 \mathrm{~m}$ in thickness (Bartz, 1974).

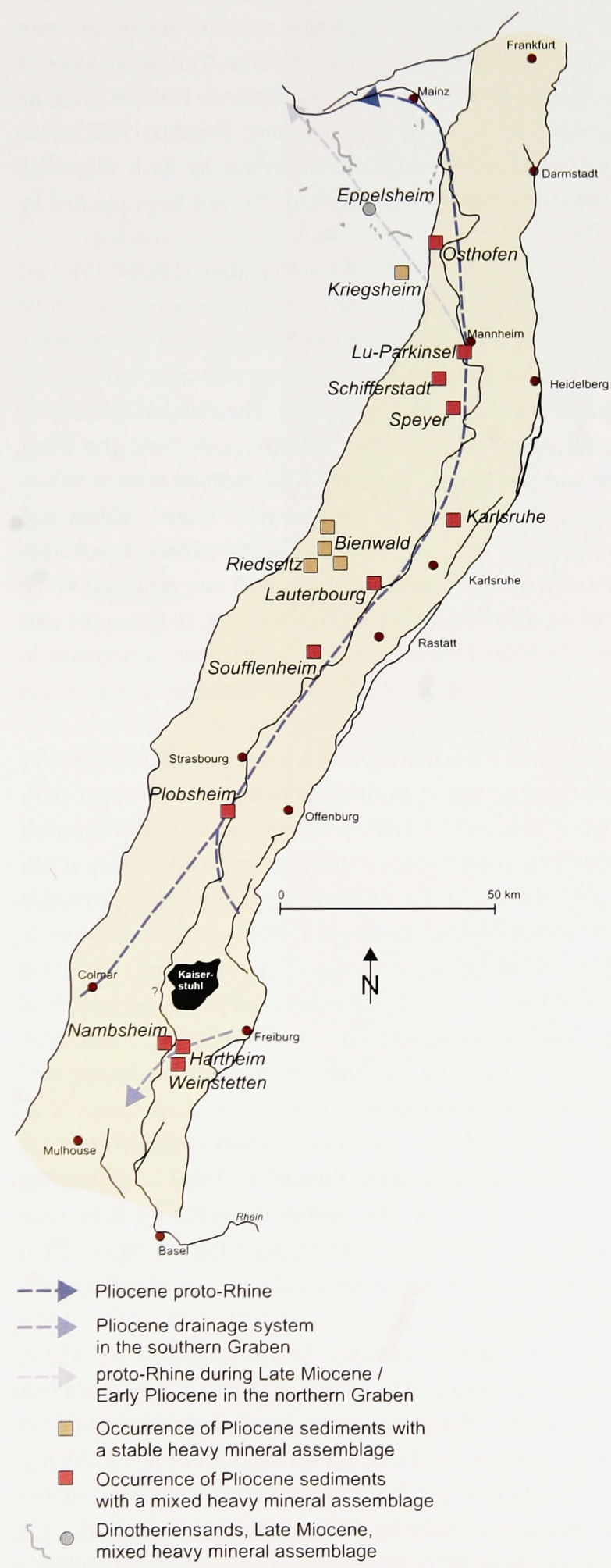

Fig. 4. Late Miocene and Pliocene course of the proto-Rhine (partly after Illies, 1965).

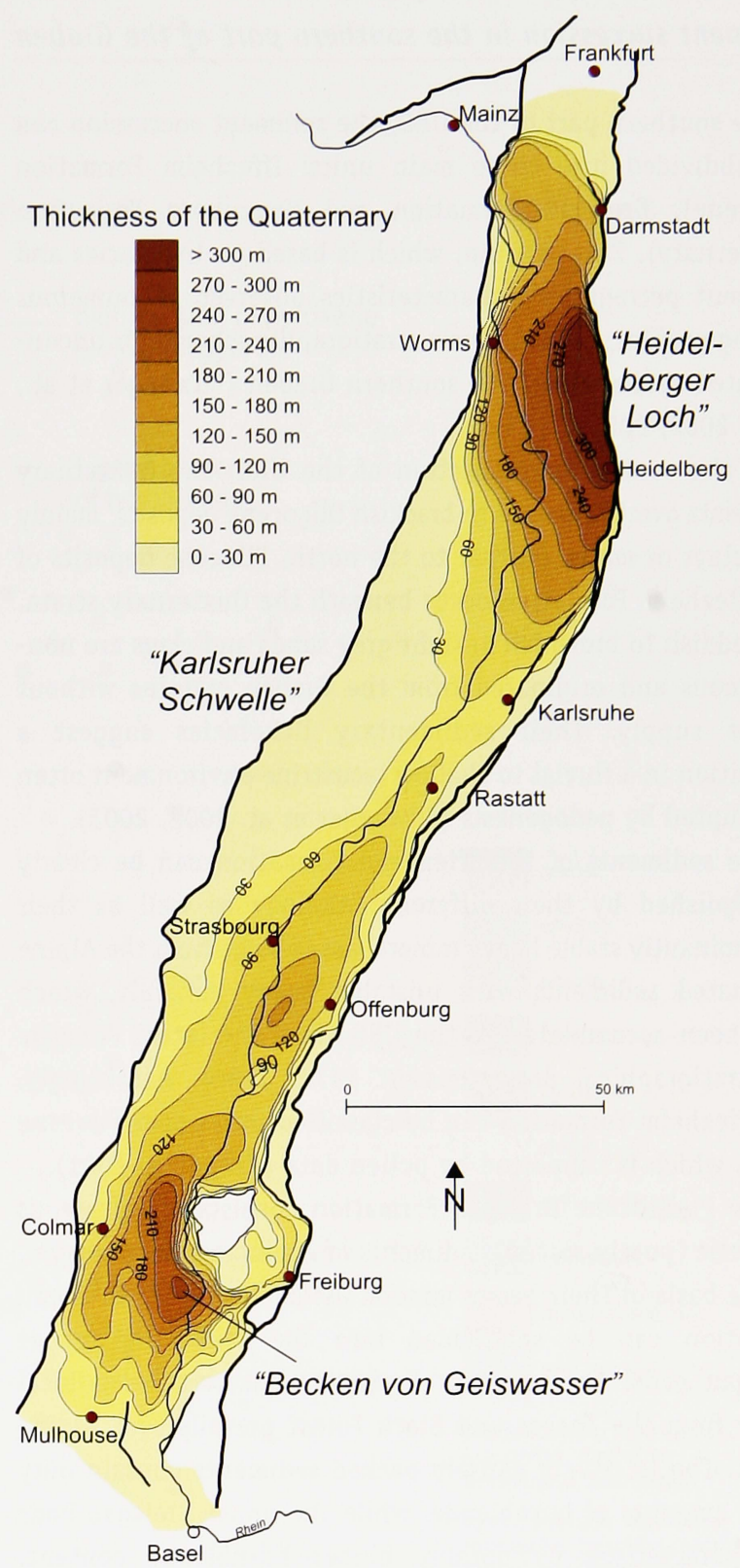

Fig. 5. Thickness of Quaternary sediments in the URG (modified after Bartz, 1974).

The correlation between the Quaternary successions in the south and the north Graben is problematic due to the variable thicknesses of the Quaternary sediments as well as their changing lithofacies. In the southernmost part of the Graben, coarse Alpine debris was deposited. Towards the north, the character of the Graben sediments changes as a result of sorting processes during fluvial transport and admixture with local material derived from the Graben margins. In the northern URG, sediments are generally finer grained, and the increased input of local material results in a far more extensive sedimentation than further to the south.

Correlations are further restricted due to the limited number of deep drillings in the northern Graben which encompass the entire Quaternary sequence. 


\section{Sediment succession in the southern part of the Graben}

In the southern part of the URG, the sediment succession can be subdivided into three main units: Iffezheim Formation (Pliocene), Breisgau Formation and Neuenburg Formation (Quaternary). This division, which is based on lithofacies and sediment petrographic characteristics observed in numerous drilling profiles, follows a new stratigraphic scheme for unconsolidated sediments of the southern Graben (Ellwanger et al., 2001, 2002, 2003).

In the southernmost section of the URG, the Quaternary sediments overlay marine to brackish Oligocene deposits, mainly dark clays or marls. Further to the north, Pliocene deposits of the Iffezheim Formation occur beneath the Quaternary strata. The reddish to brownish or light grey sands and clays are noncalcareous and originated from the Graben margins without Alpine supply. Their sedimentary lithofacies suggest a deposition in a fluvial to shallow lacustrine environment often interrupted by pedogenesis (Ellwanger et al. 2002, 2003).

The sediments of the Iffezheim Formation can be clearly distinguished by their different lithology as well as their predominantly stable heavy mineral assemblage from the Alpine dominated sediments with unstable heavy minerals, which have been accumulated in the URG since the latest Pliocene (biostratigraphical data, Geissert 1972, 1996). Accordingly, the Iffezheim Formation can be classified into upper Pliocene times, which is supported by pollen data (Knipping, 2001).

The Pleistocene Breisgau Formation consists of calcareous diamictic (poorly sorted) sediments of Alpine and local origin. On the basis of their heavy mineral assemblages, the Breisgau Formation can be subdivided into the lower and upper Breisgau beds. In the lower Breisgau beds weathered local debris from the Vosges and Black Forest prevails over Alpine gravel. The relatively densely packed sediments contain only minor amounts of hornblende, while the upper Breisgau beds are characterised by notably higher hornblende content, increasing portions of Alpine rocks and more loosely packed sediments. The Neuenburg Formation is defined by the occurrence of fresh fluvial pebbles of dominantly Alpine origin. Within the Neuenburg Formation, two coarse-grained layers of probably fluvioglacial origin with an intercalated sand-rich horizon can be correlated across the drilled profiles. Clay and recent soil form the top of the sequence.

The Breisgau Formation is probably coeval to the alpine Deckenschotter up to the MEG (Hosskirch-Komplex). A comparison of the Neuenburg Formation with sediment successions of the Rhine glacier area indicates a formation during Rissian and Würmian (Ellwanger et al., 2003).

\section{Drill core Hartheim}

The heavy mineral diagram of the drill core Hartheim (Fig. 6) serves as an example of a representative sediment record in the southern URG. The drilling Hartheim is located south of the Kaiserstuhl (Fig. 2) and reached a depth of $260 \mathrm{~m}$. The heavy mineral diagram reveals multiple changes in the mineral assemblages within the sediment record.

The lower part of the drill core (260 - 231,7 m) comprises calcareous greenish to greyish fine-grained sediments with a heavy mineral spectrum of garnet, epidote, stable and rare minerals like staurolite and glaucophane. This assemblage is characteristic for sediments of the 'Elsässer Molasse' (marine to brackish, Oligocene to Early Miocene, Boenigk, 1982). It is likely that these deposits are underlain by dark Oligocene clay, however, this stratigraphic unit has not been reached by the drilling.

The overlying Pliocene Iffezheim Formation (231,7 - 193,3 m) is represented by non-calcareous grey to grey-purple diamictic (i.e. poorly sorted) sediments including gravel of the Black Forest $(231,7-219,5 \mathrm{~m})$ and red-brown clay with intercalated red and white sand $(219,5-193,3 \mathrm{~m})$. The diamictic sediments probably reflect a deposition as mass flows from the Black Forest and the Vosges. Parts of these sediments were subsequently redeposited by a low energetic fluvial regime and accumulated as sand and clay. The heavy mineral assemblage consists of garnet as well as stable and rare minerals which confirm a source area at the Graben margins. In the upper part of the Iffezheim Formation (219,5 -193,3 m), a decrease in garnet in combination with a relative increase in stable and rare minerals can be observed.

The described subdivision into a lower part characterised by a higher percentage of unstable minerals and an upper part, which is dominated by stable minerals, has also been observed in other drill cores from the southern and middle part of the URG (Hagedorn, 2004), and therefore appears to be a characteristic feature of the Iffezheim Formation. The decrease in unstable minerals in the upper part of the Iffezheim Formation probably provides evidence for prolonged periods of surface exposure, re-deposition and weathering, which may have been caused by episodes of tectonic inactivity and reduced sedimentation rates.

Above the Iffezheim Formation, calcareous diamictons mark the beginning of the Breisgau Formation (193,3 - 54,4 m). The diamictic character of the sediments probably reflects a deposition as mass flow rather than by a fluvial regime. Their heavy mineral assemblage consists mainly of garnet and epidote, which reflects the enlarged catchment area with Alpine sediment input. Within the lower Breisgau beds (193,3 - $121 \mathrm{~m})$, the sediments contain only minor amounts of hornblende $(4 \%$ average), while a distinct increase in the hornblende content $(25 \%)$ is noticeable in the upper Breisgau beds (121 - 54,5 m).

The varieties in the hornblende content observed in the lower and upper Breisgau beds either could indicate the solution of the unstable hornblende due to weathering effects or could be the result of a change within the alpine catchment area. Granites and amphibolites mainly occurring in the 


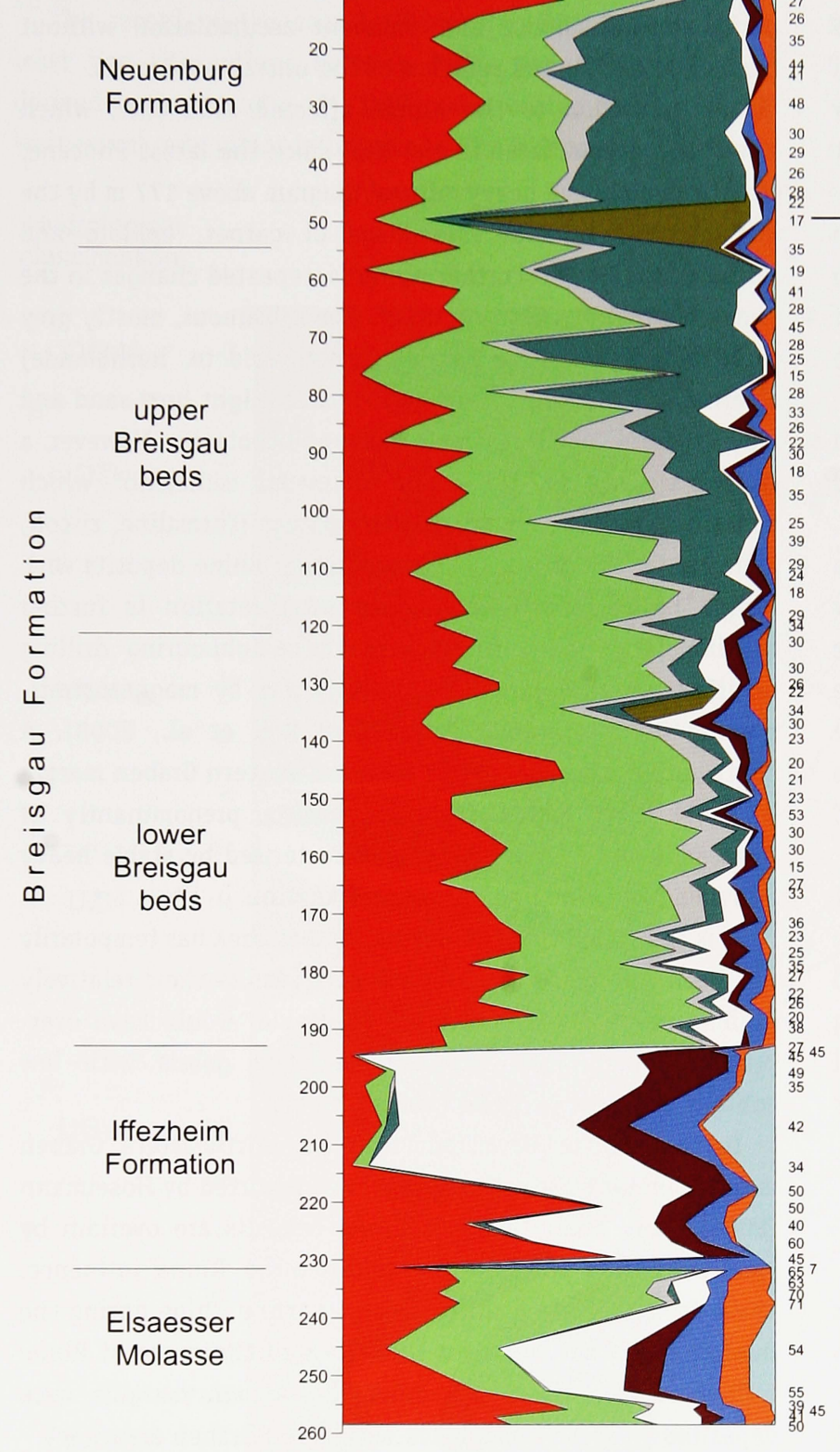

Fig. 6. Heavy mineral diagram of drill core Hartheim south of the Kaiserstuhl. high content of pyroxene (volcanic layer?)

higher content of hornblende

low content of hornblende

upper part: predominantly stable and rare heavy minerals

lower part:

higher content of instable minerals

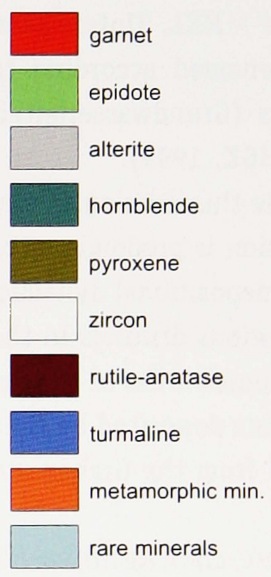

metamorphic minerals: staurolite, disthene andalusite, sillimanite rare minerals: xenotime monazite, brookite, sphene spinel, glaucophane eastern Alpine area are known as important source rocks of hornblende (Füchtbauer, 1964).

Contemporaneous sediment successions in the Freiburg Bay (near Freiburg, Fig. 2), which are free of Alpine contribution, are also characterised by low hornblende-contents in their lower part (lower Breisgau beds). This comparison suggests that weathering and solution of the unstable hornblende was probably the crucial factor for its relative decrease. This interpretation is further supported by the occurrence of several soil horizons within the sediment succession of the lower Breisgau beds, which are evidence for discontinuities during the sediment accumulation. The upper Breisgau beds on the other hand reflect a more constant and probably rapid deposition of Alpine dominated sediments.
The sediments of the Neuenburg Formation (54,5 - $0 \mathrm{~m}$ ) can be clearly distinguished from the Breisgau Formation by their mainly fluvial lithofacies consisting of well-sorted gravel and sand. However, the heavy mineral assemblage is similar to that observed in the upper Breisgau beds, which indicates a continuing accumulation of predominantly Alpine debris.

An unusual occurrence of a high percentage of pyroxene was noticed in one sample from the Hartheim core retrieved from a depth of about $50 \mathrm{~m}$, which suggests the input of volcanic material into this horizon. This could be a very useful marker for the chronological classification of these sediments, therefore an absolute dating is intended. 


\section{Sediment succession in the northern part of the Graben}

In the northern part of the URG, the diamictic character of the Breisgau Formation fades due to more frequent fluvial reworking. Here, the Graben sediments are generally finer grained, better sorted and mixed with local sediment input from the Graben margins. Therefore, the newly defined stratigraphic scheme for unconsolidated sediments of the southern URG (Ellwanger et al., 2001, 2002, 2003) cannot be applied to the Pleistocene sediment successions of the northern part of the URG so far. Additionally, reliable age determinations are presently not available.

In this area, this study adheres to the established lithological distinction between gravel layers ('Kieslager') and intercalated fine-grained horizons ('Zwischenhorizonte' $0 \mathrm{ZH}$, UZH, after Bartz, 1982, Fig. 1). The chronological classification of these units has recently been revised on the basis of new age data (c.f. Weidenfeller \& Kärcher, 2008). Furthermore, the gravel layers ('Oberes Kieslager' - OKL, 'Mittlere sandig-kiesige Abfolge' - MKL, 'Untere sandig-schluffige Abfolge' - UKL) have been renamed according to their hydrological properties as aquifers (Grundwasserleiter $=0 \mathrm{GWL}$, MGWL, UGWL, Kärcher, 1987; HGK, 1999).

While this lithological/hydrological division of the sediment succession is predominantly based on grain size and therefore on the depositional dynamics, the petrographic results obtained from various drillings in the northern Graben reveal changing paleo-source areas of the Quaternary Graben sediments. Fluvial sediments deposited by the Rhine alternate with fluvial debris derived from the Graben margins.

\section{Drill core Ludwigshafen-Parkinsel}

The $300 \mathrm{~m}$ deep core drilling of Ludwigshafen-Parkinsel is located in the central northern URG (Fig. 2). The sequence can be subdivided into the Pliocene and the Quaternary deposits (cf. Weidenfeller \& Kärcher, 2008; Rolf et al., 2008). Figure 7 illustrates the obtained heavy mineral assemblages of the sediment succession.

The non-calcareous Pliocene sediments from a depth below $177 \mathrm{~m}$ are characterised by a mixed heavy mineral spectrum with stable and instable minerals (Fig. 7). This indicates a provenance of the sediments from the crystalline rocks of the graben margins (Black Forest, Vosges, Buntsandstein of the Odenwald and Pfälzerwald, Fig. 2), with a following fluvial transport within the URG to the North. The palaeomagnetic measurements show a normal polarisation indicating a sediment accumulation during the Gauss epoch (2.581 3.58 Ma; Rolf, 2004).

The upper part of the Pliocene sediments does not display any significant changes in their heavy mineral distribution, different from the pattern observed in sediments in the southern and middle URG, where the upper part of the Pliocene
Iffezheim Formation is characterised by decreasing contents of unstable mineral fraction (Fig. 6). This suggests prolonged periods of subsidence and sediment accumulation without major weathering and solution of the unstable minerals.

The transition to the Alpine affected sediments, which have been accumulated in the URG since the latest Pliocene, is noticeable in the heavy mineral diagram above $177 \mathrm{~m}$ by the characteristic mineral assemblage of garnet, epidote and hornblende (Fig. 7). Further upwards, repeated changes in the heavy mineral distribution occur. The calcareous, mostly grey sand deposited by the Rhine (garnet, epidote, hornblende) alternates with non-calcareous reddish to light grey sand and clay deposits, which resemble Pliocene lithofacies. However, a Quaternary age for those non-calcareous sediments, which contain a stable heavy mineral assemblage (turmaline, zircon, anatase), is evidenced by the underlying Rhine deposits with Alpine input. This chronological interpretation is further confirmed by pollen findings in the neighbouring drilling Schifferstadt (Knipping, 2002, 2004) and by magnetostratigraphic interpretations (Rolf, 2004; Rolf et al., 2008). A contribution of fluvial debris from the western Graben margin is likely. This region (Fig. 2) consists predominantly of Buntsandstein petrographically characterised by stable heavy minerals like turmaline, zircon and anatase.

It is concluded that the western Graben area has temporarily not been influenced by Rhine deposition, as their relatively high content of heavy minerals (unstable) would have overprinted signals from the Buntsandstein debris with low content of heavy minerals (stable).

In the area of Darmstadt near the northeastern Graben margin similar observations have been reported by Hoselmann (2004). Here also calcareous Rhine deposits are overlain by local sediments without any evidence for Rhine influence. These facts indicate a shifting course of the Rhine during the Quaternary in the northern URG. Beyond the range of Rhine influence, local sediments from the Graben margins were deposited in great thicknesses within the Graben area.

The shifting courses of the Rhine and the local rivers may be caused by tectonic movements of the different Graben blocks and the Graben margins (c.f. Weidenfeller \& Kärcher, 2004, 2008). The Rhine may have temporarily followed the rapidly subsiding area near the eastern margin of the Graben ('Heidelberger Loch', Fig. 5). The sporadic Rhine deposits at the western Graben margin could have been accumulated during times, when this part of the Graben has also been subjected to tectonic lowering (e.g. beginning of the Quaternary, Late Weichselian).

Furthermore, the ratio of sediment supply between the Rhine and local margins had an important influence on the sediment deposition. Phases of massive Rhine supply (e.g. deglaciation) and aggradation in the Graben may enable the lateral movement of the Rhine over the whole Graben area. On the contrary, phases of floodplain stability or even slight 
incision of the Rhine may lead to propagation of the river systems from the Graben margins towards the Graben.

The record of the core Ludwigshafen-Parkinsel shows at least five alternations between Rhine deposits and locally derived sediments (Fig. 7). Drill cores located further to the west reveal only minor influences of Rhine deposition, whereas drill cores from areas further to the east are dominated by Rhine sediments. In this context, the drilling LudwigshafenParkinsel appears to be located in an area, where both sediment types show interfingering (Fig. 8).

The presented results are summarised in a schematic crosssection through the western margin of the northern URG

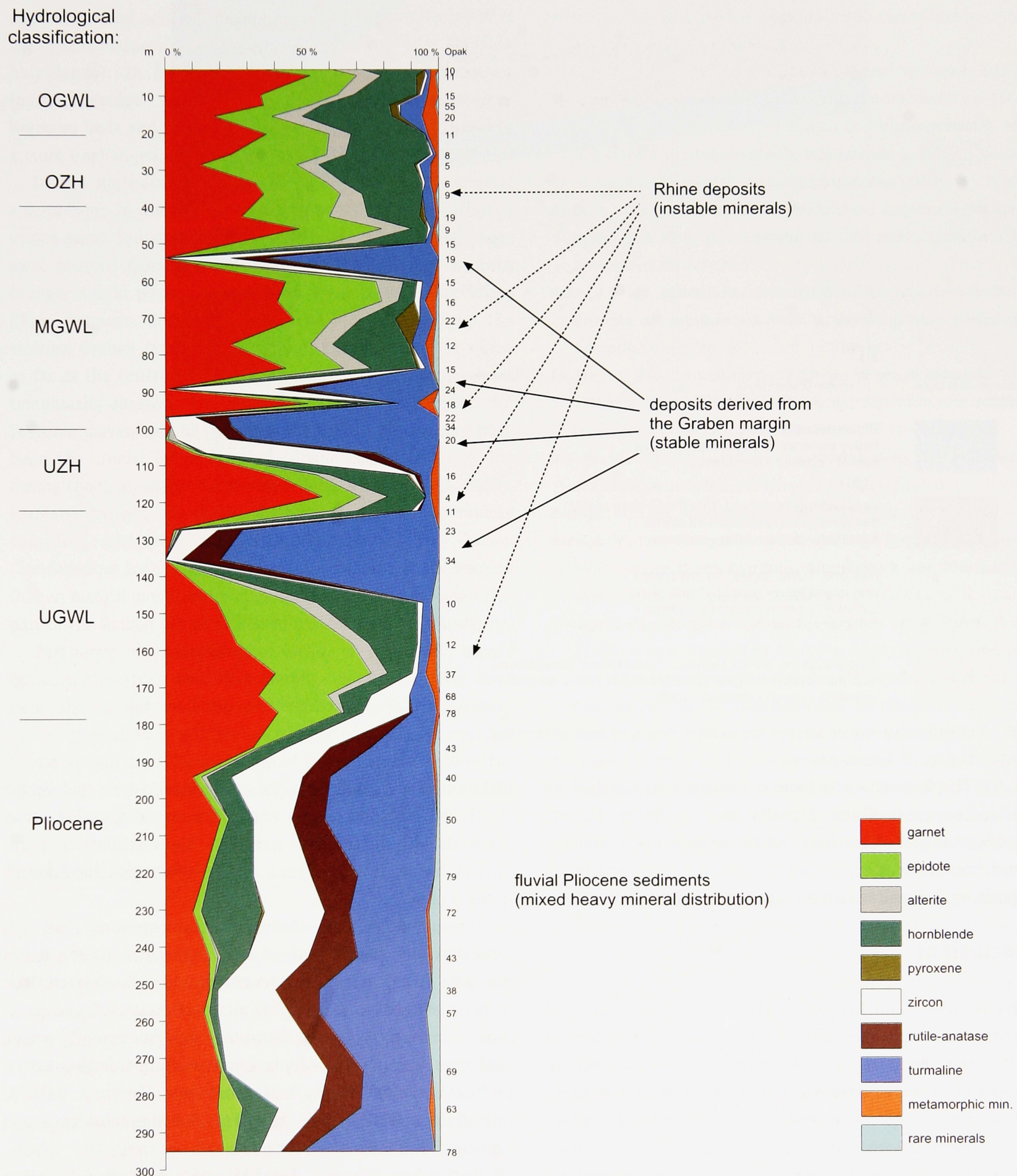

Fig. 7. Heavy mineral diagram of drill core Ludwigshafen-Parkinsel in the northern URG. OGWL - Oberer Grundwasserleiter / upper aquifer; OZH - Oberer Zwischenhorizont / upper fine grained horizon; MGWL - Mittlerer Grundwasserleiter / middle aquifer; UZH - Unterer Zwischenhorizont / lower fine grained horizon; UGWL - Unterer Grundwasserleiter / lower aquifer). 
W

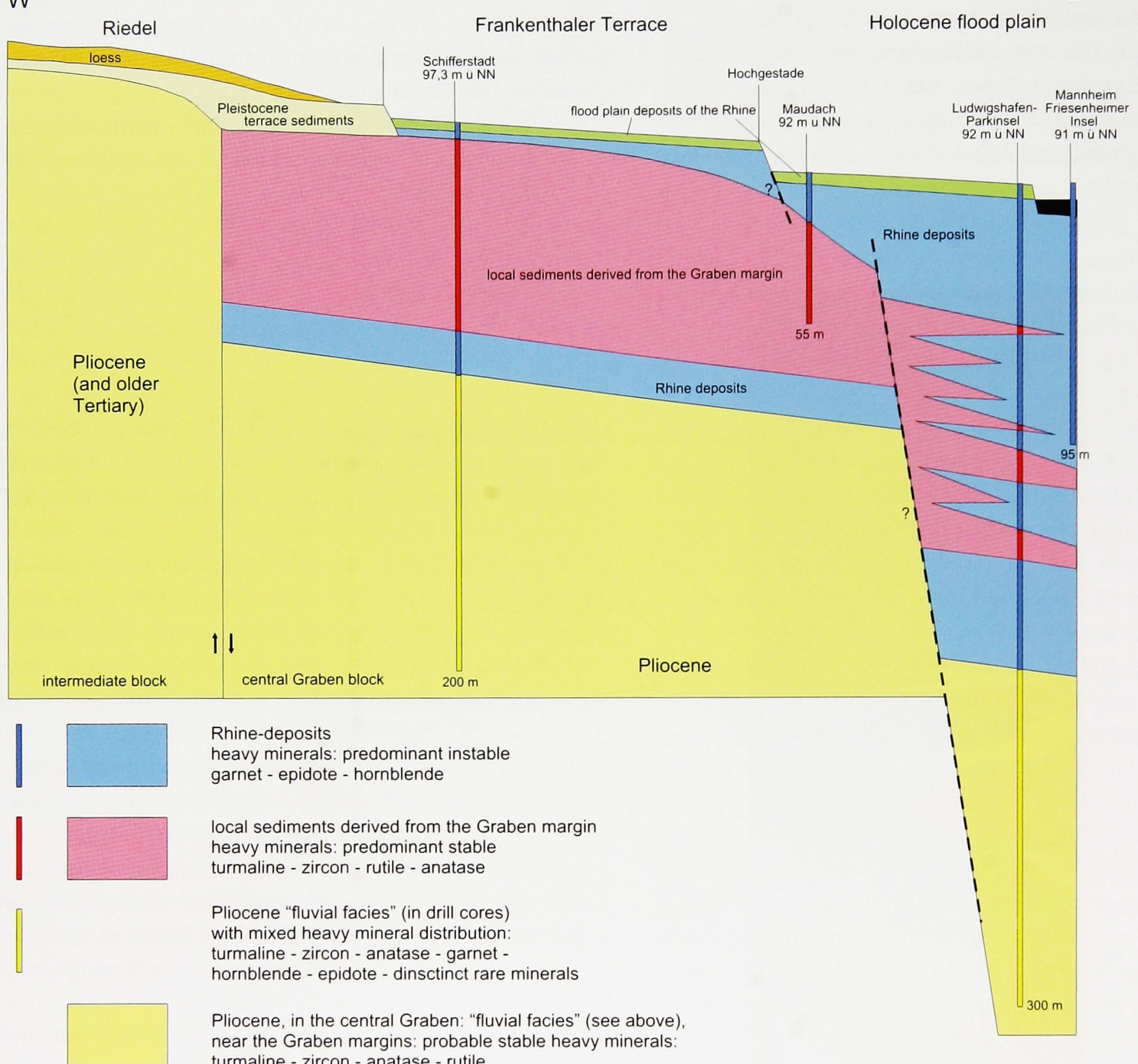

Fig. 8. Schematic cross-section through the western margin of the northern URG.

(Fig. 8). The Quaternary sediments can be distinguished by their source area: Rhine deposits with a heavy mineral assemblage of garnet, epidote and hornblende and sediments derived from the western Graben margin with a stable mineral composition (turmaline, zircon, anatase).

\section{Conclusions}

The detailed investigation of various drill cores provided significant information regarding the depositional history of the Pliocene and Quaternary sediments within the URG. On the basis of heavy mineral and lithofacies analyses the likely paleo-sources for the sediments as well as post-sedimentary processes could be reconstructed.

Within the Pliocene sediments, two heavy mineral assemblages can be distinguished. The first one indicates sources in Buntsandstein areas exposed along the Graben margins (stable heavy minerals). The other one reflects a contribution of debris of the crystalline rocks of the Black Forest and Vosges by fluvial transport to the north (stable and unstable heavy minerals with distinct rare minerals). The distribution of this fluvial facies gives evidence of the course of the Pliocene proto-Rhine.

The upper part of the Pliocene successions from the southern and middle part of the URG shows a decrease in unstable heavy minerals in combination with characteristic lithofacies (soil horizons). This suggests prolonged periods of non-deposition or limited deposition and concurrently acting surface weathering. A likely interpretation for this observation is, that tectonic activity halted deposition in these parts of the Graben, while in the northern URG the subsidence and sediment accumulation continued.

In the Late Pliocene, the Rhine was connected with the Alpine drainage system and transported Alpine debris and heavy minerals (garnet, epidote, hornblende) into the Graben. 
In the southern URG, where intercalated fine-grained horizons are missing, a new stratigraphic organisation of the unconsolidated sediment succession was established by means of sequence stratigraphy and heavy mineral analyses (Iffezheim Formation, Breisgau Formation, Neuenburg Formation).

During the formation of the lower Breisgau beds repeated discontinuities in deposition, commonly accompanied by weathering and soil formation, probably caused alteration in the heavy mineral assemblage (decrease of the unstable hornblende). In contrast, the original mineral assemblage (garnet, epidot, hornblende) is preserved in the upper Breisgau beds and in the Neuenburg Formation as a result of a more unchanged and rapid sedimentation.

In the northern URG, two distinguishable heavy mineral assemblages in the Quaternary sediments indicate different source areas. Sediments with a stable heavy mineral assemblage were sourced from the Buntsandstein areas of the western Graben margin whereas an unstable assemblage characterises Rhine deposits. Considering that the local debris from the western Graben margin (Pfälzerwald) can be traced unmixed as far as the centre of the Graben, the Rhine must have been temporarily absent in the western part of the Graben (Fig. 8). Tectonic movements of the different Graben blocks may have been the crucial factor for the shifting course of the Rhine during the Quaternary (c.f. Weidenfeller \& Kärcher, 2004, 2008). For long periods, the Rhine may have followed the rapidly subsiding area near the eastern margin of the Graben ('Heidelberger Loch'). The sporadic Rhine deposits at the western Graben margin must have accumulated during times, when this part of the Graben has also been subjected to tectonic lowering.

Furthermore, the changing ratio of sediment supply between the Rhine and local margin rivers could have been determining. Massive Alpine sediment supply into the Graben probably resulted in a lateral movement of the Rhine over the whole Graben area. During times of floodplain stability of the Rhine the local river systems from the Graben margins could extend into the Graben.

\section{Acknowledgements}

We wish to thank our colleagues Dr D. Ellwanger, Dr G. Wirsing, I. Neeb (Landesamt für Geologie, Rohstoffe und Bergbau Baden-Württemberg), Dr M. Weidenfeller, Dr T. Kärcher (Landesamt für Geologie und Bergbau Rheinland-Pfalz), Dr P. Elsass (Bureau de Recherches Géologiques et Minières), Dr C. Hoselmann (Hessisches Landesamt für Umwelt und Geologie), Dr M. Knipping (University of Hohenheim), Dr C. Rolf (Leibniz Institute for Applied Geosciences) for their support to this study. The German Science Foundation (DFG) financially supported parts of this research, also the Landesamt für Geologie, Rohstoffe und Bergbau Baden-Württemberg, the Bureau de Recherches Géologiques et Minières and the Gewässerdirektion Südlicher Oberrhein.

\section{References}

Bartz, J., 1950. Das Jungpliozän im nördlichen Rheinhessen. Notizblatt des Hessischen Landesamtes für Bodenforschung zu Wiesbaden VI 1: 201-243.

Bartz, J., 1953. Revision des Bohrprofils der Heidelberger Radium-Sol-Therme. Jahresberichte und Mitteilungen des Oberrheinischen Geologischen Vereines N.F. 33: 101-125.

Bartz, J., 1959. Zur Gliederung des Pleistozäns im Oberrheingebiet. Zeitschrift deutsche geologische Gesellschaft 111: 653-661.

Bartz, J., 1961. Die Entwicklung des Flussnetzes in Südwestdeutschland. Jahreshefte des Geologischen Landesamts Baden-Württemberg 4: 127-135.

Bartz, J., 1974. Die Mächtigkeit des Quartärs im Oberrheingraben. In: Illies, J. H. \& Fuchs, K. (eds): Approaches to Taphrogenesis. Inter-Union-Commission on Geodynamics Scientific Report 8, Schweitzerbart (Stuttgart): 78-87.

Bartz, J., 1976. Quartär und Jungtertiär im Raum Rastatt, mit Beiträgen von Brelie, G. \& Maus, H. Jahreshefte des Geologischen Landesamts BadenWürttemberg 18: 121-178.

Bartz, J., 1982. Quartär und Jungtertiär II im Oberrheingraben im Großraum Karlsruhe mit Beiträgen von Brelie, G. von der \& Maus, H. Geologisches Jahrbuch A 63: 3-237.

Bludau, W., 1995. Biostratigraphische Untersuchungen an Sedimenten aus dem mittleren Oberrheingraben - Vorläufige Ergebnisse. Jahreshefte des Geologischen Landesamts Baden-Württemberg 35 (1993): 395-406.

Boenigk, W., 1982. Der Einfluß des Rheingraben-Systems auf die Flußgeschichte des Rheins. Zeitschrift für Geomorphologie N.F. 42: 167-175.

Boenigk, W., 1983. Schwermineralanalyse. Enke (Stuttgart): 152 pp.

Boenigk, W., 1987. Petrographische Untersuchungen jungtertiärer und quartärer Sedimente am linken Oberrhein. Jahresberichte und Mitteilungen des Oberrheinischen Geologischen Vereines N.F. 69: 357-394.

Ellwanger, D., Bibus, E., Bludau, W., Hagedorn, E. \& Storch, H., 2001. Ansätze zu einer Sequenz bzw. Klima-Eventstratigraphie der Lockergesteine des südwestdeutschen Alpenvorlandes (Oberschwaben und Oberrhein). Extended Abstract, ICDP/KTB-Kolloquium; Ruhr-Universität Bochum, 7-8. Juni 2001.

Ellwanger, D., Hinderer, M., Lämmermann-Barthel, J., Neeb, I., Bibus, E., Hagedorn, E. \& Villinger, E., 2002. Sedimentbilanzierungen in quartären und pliozänen Lockergesteinen (Rheingletscher, Mittellandgletscher, Oberrheingraben). ICDP/ODP-Kolloquium; Universität Potsdam, 6-8. Juni 2002

Ellwanger, D., Lämmermann-Barthel, J. \& Neeb, I., 2003. Eine 'Landschaftsübergreifende Lockergesteinsgliederung' vom Alpenrand bis zum Oberrhein. GeoArchaeoRhein 4: 81-125.

Engesser, W. \& Münzing, K., 1991. Molluskenfaunen aus Bohrungen im Raum Philippsburg-Mannheim und ihre Bedeutung für die Quartärstratigraphie des Oberrheingrabens. Jahreshefte des Geologischen Landesamts BadenWürttemberg 33: 97-117.

Füchtbauer, H., 1964. Sedimentpetrographische Untersuchungen in der älteren Molasse nördlich der Alpen. Eclogae geol. Helv., 57/1 (Basel): 157-298.

Geissert, F., 1972. Neue Untersuchungen im Pliozän der Hagenauer Umgebung (Nördliches Elsaß). Mainzer naturwissenschaftliches Archiv 11: 191-221.

Geissert, F., 1996. Paläontologie des Pliozäns und Quartärs im Unterelsaß (Département Bas-Rhin). Jahresberichte und Mitteilungen des Oberrheinischen Geologischen Vereines N.F. 78: 209-219. 
Hagedorn, E.-M., 2004. Sedimentpetrographie und Lithofazies der jungtertiären und quartären Sedimente im Oberrheingebiet. Inaugural-Dissertation, Geologisches Institut der Universität zu Köln: 248 pp. http://kups.ub.unikoeln.de/volltexte/2004/1253/

HGK, 1999. Hydrogeologische Kartierung und Grundwasserbewirtschaftung Rhein-Neckar-Raum. Fortschreibung 1983-1998. Ministerium für Umwelt und Verkehr Baden-Württemberg, Hessisches Ministerium für Umwelt, Landwirtschaft und Forsten, Ministerium für Umwelt und Forsten RheinlandPfalz: 155 pp.

Hoselmann, C., 2004. Quartärgeologische Untersuchungen an der geplanten ICE-Trasse Frankfurt (Main) - Mannheim, Nördlicher Oberrheingraben. In: Vandenberghe, J., Kasse, K. \& Van Balen, R. (eds): From Source to Delta DEUQUA meeting Nijmegen (30.08. - 3.09.2004). Abstract Volume (p. 45).

Illies, H., 1965. Bauplan und Baugeschichte des Oberrheingrabens. Ein Beitrag zum 'Upper Mantle Project'. Oberrheinische geologische Abhandlungen 14: 1-54.

Kärcher, T., 1987. Beiträge zur Lithologie und Hydrogeologie der Lockergesteinsablagerungen (Pliozän, Quartär) im Raum Frankenthal, LudwigshafenMannheim, Speyer. Jahresberichte und Mitteilungen des Oberrheinischen Geologischen Vereines N.F. 69: 279-320.

Knipping, M., 2001. Arbeitsbericht über Pollenanalytische Untersuchungen im Rahmen des ICDP/KTB-Projektes 'Paläoklimatisch-sedimentologische Untersuchungen an Forschungsbohrungen im Alpenvorland'. Internal report LGRB Baden-Württemberg (unpubl.): $11 \mathrm{pp}$.

Knipping, M., 2002. Pollenanalytische Untersuchungen am Profil 'Schifferstadt BK 30c GM'. Internal report Landesamt für Geologie und Bergbau RheinlandPfalz (unpubl.): $11 \mathrm{pp}$.

Knipping, M., 2004. Pollenanalytische Untersuchungen an tiefen Kernbohrungen im nördlichen Oberrheingraben. In: Vandenberghe, J., Kasse, K. \& Van Balen, R. (eds): From Source to Delta - DEUQUA meeting Nijmegen (30.08. - 3.09.2004) - Abstract Volume (p. 52).

Münzing, K., 1981. Pliozäne Mollusken aus der Umgebung von Rastatt und Philippsburg (Oberrheingraben, Baden-Württemberg). Jahresberichte und Mitteilungen des Oberrheinischen Geologischen Vereines N.F. 63: 151-156.

Rolf, C., 2004. Magnetostratigraphie und Gesteinsmagnetik an Bohrkernen der Bohrung Ludwigshafen/Parkinsel. Report GGA-Institut Hannover (unpubl.) $32 \mathrm{pp}$.

Rolf, C., Hambach, U. \& Weidenfeller, M., 2008. Rock and palaeomagnetic evidence for the Plio-Pleistocene palaeoclimatic change recorded in Upper Rhinegraben sediments (Core Ludwigshafen-Parkinsel). Netherlands Journal of Geosciences 87/1: 41-50.

Roll, A., 1979. Versuch einer Volumenbilanz des Oberrheintalgrabens und seiner Schultern. Geologisches Jahrbuch A 52: 3-82.

STD, 2002. Deutsche Stratigraphische Kommission: Stratigraphische Tabelle von Deutschland.

Van Andel, T.H., 1950. Provenance, Transport and Deposition of Rhine Sediments. Veenman \& Zonen (Wageningen): $129 \mathrm{pp}$.

Walter, R., 1992. Geologie von Mitteleuropa. 5th edition, $561 \mathrm{pp}$

Weidenfeller, M. \& Kärcher, T., 2004. Terrassen, Kieslager und Zwischenhorizonte - neue Aspekte zur geologisch-hydrogeologischen Gliederung der quartaren Sedimente im linksrheinischen Teil des nördlichen Oberrheingraben. In: Vandenberghe, J., Kasse, K. \& Van Balen, R. (eds): From Source to Delta DEUQUA meeting Nijmegen (30.08. - 3.09.2004). Abstract Volume (p. 88).
Weidenfeller, M. \& Kärcher, T., 2008. Tectonic influence on fluvial preservation: Aspects of the architecture of Middle and Late Pleistocene sediments in the northern Upper Rhine Graben. Netherlands Journal of Geosciences 87/1: 33-40. 